\title{
Para construir outro olhar: notas sobre o ensino de história e cultura africanas e afro-brasileiras
}

To build another look: notes on the teaching of African and Afro-Brazilian history and culture

Hilton Costa*

\section{Resumo}

O presente texto busca destacar a importância da construção de um novo olhar no que diz respeito ao ensino de história e cultura africanas e afro-brasileiras. O texto se divide em dois momentos: o primeiro versa sobre a importância da alteração da Lei de Diretrizes e Bases da Educação brasileira, por meio da Lei 10.639/2003, e sua relação com a formação de docentes. O segundo aponta para uma sugestão de trabalho em sala de aula: parte-se do contexto intelectual pós-abolição no Brasil, indicando sua relação com o senso comum e a maneira como este articula a manutenção de estereótipos e estigmas acerca da população negra no Brasil.

Palavras-chave: educação; cultura e história afro-brasileiras; relações raciais.

\begin{abstract}
This paper seeks to emphasize the importance of constructing a new perspective regarding the teaching of African and Afro-Brazilian history and culture. The text is divided in two sections: the first relates to the importance of the changing of the Law of Guidelines and Bases of Brazilian Education, by means of the Law 10.639/2003 and its relationship with the process of training teachers. The second suggests a way to work with the issue in classrooms: as a part of the intellectual context in post-abolition in Brazil, indicating the liaison with common sense and the ways in which it reinforces the maintenance of stigmas and stereotypes about black population in Brazil.

Keywords: education; afro-brazilian history and culture; racial relationship.
\end{abstract}

\footnotetext{
* Doutorando em História. Programa de Pós-Graduação em História, Universidade Federal do Paraná (UFPR). Rua General Carneiro, 460, sala 716, 7º andar, Ed. Dom Pedro I, Centro. 80060150 Curitiba - PR - Brasil. angolapr@yahoo.com
} 
Para ser mais claro: excluindo um seleto grupo de intelectuais e pesquisadores, uma parcela dos afrodescendentes e pessoas iluminadas pelas noções do relativismo cultural, nós, brasileiros, tratamos a África de forma preconceituosa. Reproduzimos em nossas ideias as notícias que circulam pela mídia, e que revelam um Continente marcado pelas misérias, guerras étnicas, instabilidade política, aids, fome e falência econômica. Às imagens e informações que dominam os meios de comunicação, os livros didáticos incorporam a tradição racista e preconceituosa de estudos sobre o Continente e a discriminação à qual são submetidos os afrodescendentes aqui dentro. ${ }^{1}$

O espaço escolar, desde pelo menos a Reforma Protestante, no século XVI, ganhou centralidade na vida das pessoas no mundo ocidental. A escola se tornou, em teoria, algo obrigatório às pessoas, seja pela necessidade de se ajustar à sociedade envolvente, seja pela imposição do Estado, ou ainda pela combinação das duas situações. No Brasil, uma pessoa que consiga cumprir o percurso educacional formal deverá passar de 12 a 13 anos na escola. E nisso se excluem os períodos anteriores à inserção no ensino fundamental, o momento outrora denominado pré-escolar, e o ensino superior. Desta feita, durante um período de 12 ou 13 anos uma pessoa pode vir a passar de quatro a cinco horas diárias no espaço escolar. Logo, não é difícil admitir a relevância da escola enquanto ambiente essencial de socialização admitida em sentido amplo. ${ }^{2}$

A socialização é assim entendida porque não diz respeito somente à relação da/do discente com os conteúdos das diferentes disciplinas, mas também à convivência com as/os colegas, professoras/es, funcionários/as. É nesse universo que inúmeras pessoas estabelecem suas primeiras relações de amizade/ inimizade, de trabalho em equipe, reconhecem as primeiras sensações de sucesso/insucesso. Ou seja, a escola é o primeiro local onde as pessoas são apresentadas a inúmeras situações da vida social, circunstâncias mais amplas e complexas, na maioria dos casos, do que aquelas vividas no ambiente familiar, primeiro ambiente de vida social para muitos. A escola, mesmo sendo confessional ou militar, as expõe às diferenças, diferenças estas que dão uma dimensão mais próxima do que é a vida social nas sociedades modernas. É no ambiente escolar, também, que se dá a necessidade de lidar com a diferença.

De um modo geral e generalizante, a tendência é trabalhar com a diferença, com as diferenças, fazendo uso de algumas ferramentas interpretativas. Tais 
ferramentas compõem a forma ou as formas como as pessoas lidam com o mundo à sua volta. Elas são aqui agregadas na expressão conceitual: visão de mundo. Esta é elemento essencial, básico para a interação dos indivíduos com a sociedade. É construída em vários espaços sociais e, evidentemente, a escola é um deles, talvez um dos mais importantes. A escola fornece elementos essenciais à forma como elas vão ler e interagir com o mundo à sua volta. Assim sendo, a atuação docente e dos programas escolares é decisiva à composição da forma como muita gente vai perceber o mundo. Desta feita, mostra-se necessário a quase toda e qualquer tentativa de rever posições e ideias socialmente arraigadas que passe por um diálogo sério com professores/as, educadores/ as e pelos programas escolares. As mencionadas posições arraigadas não o são desde sempre, elas foram se tornando sócio-historicamente o que são. De modo a poderem ser desarraigadas.

Assim, voltando diretamente ao tema que propomos tratar aqui, perguntamos: o que sabemos sobre a África, suas populações, civilizações? Ou sobre a população negra do Brasil? Anderson Ribeiro Oliva, em artigo publicado em 2003, mesmo ano da Lei 10.639, faz observações importantes acerca da imagem da África no Brasil. Apesar das mudanças em curso nos últimos anos, suas colocações são pertinentes. Além daquelas presentes no excerto que serve de epígrafe para o presente texto, Oliva ainda destaca que:

Para além da educação escolar falha, é certo afirmar que as interpretações racistas e discriminatórias elaboradas sobre a África e incorporadas pelos brasileiros são resultado do casamento de ações e pensamentos do passado e do presente ...

As distorções, simplificações e generalizações de sua história e de suas populações são comuns a várias partes e tempos do mundo ocidental. Dessa forma, se continuarmos a reproduzir leituras e falas ... é muito provável que o imaginário de nossas futuras gerações sobre a África não sofra modificações significativas. (Oliva, 2003, p.431)

Oliva informa acerca da existência de posições, imagens bastante arraigadas acerca da África, suas populações e civilizações, bem como sobre história e cultura afro-brasileiras no cotidiano escolar. Posições e imagens, em geral, postas a apresentar visões, se não negativas, pelo menos estereotipadas. E isso se dá em um local importante para a formação da visão de mundo das pessoas. De fato, como se buscará apresentar adiante, essa situação vem se alterando, 
mas ainda há no senso comum, no senso comum escolar, no senso comum acadêmico, imagens distorcidas da África e de suas civilizações, há muito arraigadas. Tais imagens foram, em grande medida, construídas pelo colonialismo, pelo neocolonialismo e também pela nova onda de hegemonia euro-estadunidense nomeada de globalização. A produção cultural e intelectual vinculada de alguma maneira à visão de mundo desses movimentos difundiu e fixou a imagem da região como o local de guerras endêmicas, ou ainda a do lugar sem humanidade, espaço do natural por excelência, lar dos grandes mamíferos das savanas e do Saara. E seus povos foram vistos como atrasados. Esse rol de estigmas e estereótipos, infelizmente, ainda persiste quando a África é discutida em sala de aula. De fato, existem inúmeros conflitos armados no continente africano, há a epidemia de aids, há a fome, e lá estão os grandes mamíferos e o Saara; a questão é que a África não se resume a isso. Com efeito, devemos chamar a atenção para o fato de que em se olhando para essas situações com outro olhar pode-se buscar compreender o processo que as formou - os motivos dos conflitos armados, por exemplo - e analisar vários aspectos, como o fato de que o Saara aumenta a cada ano.

Um tratamento estigmatizado e estereotipado também foi dado - e infelizmente ainda o é - à história e à cultura dos descendentes de africanas e africanos do Brasil. Essa população tem sua imagem associada recorrentemente à violência, à pobreza, à indolência e a uma sexualidade animalesca, ou seja, a um rol de características negativas. E quando se almeja valorizá-la, isso se dá por meio de outro estereótipo, o da 'festividade', ou seja, pela alegoria de pessoas aptas a fazerem 'festas', mas inaptas a responsabilidades de outra ordem. Nesse caso, como no anterior, outro olhar pode revelar, em vez de estereótipos, os processos sócio-históricos que produziram a situação que leva parte considerável da população negra brasileira a viver se não na pobreza, muito perto dela. Mas para tudo isso ser viável é necessário preparar o olhar para ver outras coisas, para além dos estereótipos, e, evidentemente, ter a vontade de ver outra coisa. A construção desse outro olhar é possivelmente um dos principais objetivos da Lei 10.639/2003. Pois a constituição de outro olhar é fundamental para o rompimento da situação mencionada.

Desta feita, o presente texto se divide em dois momentos: o primeiro versa sobre a importância da alteração da Lei de Diretrizes e Bases da Educação brasileira e sua relação com a formação de docentes. E nesse sentido é impos- 
sível ignorar a democracia racial, elemento dos mais importantes à formação da visão de mundo dos/as brasileiros/as, bem como à sua contestação. $\mathrm{O}$ segundo momento aponta para uma sugestão de trabalho em sala de aula: parte-se do contexto intelectual pós-abolição no Brasil, indicando sua relação com o senso comum e analisando como este articula a manutenção de estereótipos e estigmas acerca da população negra no Brasil. Essa sugestão é uma tentativa de exemplificar a constituição desta outra forma de olhar.

\section{A importância da Alteração da Lei de Diretrizes e Bases}

O ano de 2003 constitui um momento importante na reestruturação da forma como deveriam ser abordados no ensino escolar brasileiro os conteúdos referentes à África, às suas populações e à população afro-brasileira. É nesse ano que se dá a aprovação e sanção da Lei federal de número 10.639, a lei que estabeleceu alterações na Lei de Diretrizes de Bases da Educação (LDB), esta datada de 1996:

O PRESIDENTE DA REPÚBLICA faço saber que o Congresso Nacional decreta e eu sanciono a seguinte Lei:

Art. $1^{\circ}$. A Lei $\mathrm{n}^{\circ}$ 9.394, de 20 de dezembro de 1996, passa a vigorar acrescida dos seguintes arts. 26-A, 79-A e 79-B:

Art. 26-A. Nos estabelecimentos de ensino fundamental e médio, oficiais e particulares, torna-se obrigatório o ensino sobre História e Cultura Afro-Brasileira.

$\$ 1^{\circ}$. O conteúdo programático a que se refere o caput deste artigo incluirá o estudo da História da África e dos Africanos, a luta dos negros no Brasil, a cultura negra brasileira e o negro na formação da sociedade nacional, resgatando a contribuição do povo negro nas áreas social, econômica e política pertinentes à História do Brasil.

$\$ 2^{\circ}$. Os conteúdos referentes à História e Cultura Afro-Brasileira serão ministrados no âmbito de todo o currículo escolar, em especial nas áreas de Educação Artística e de Literatura e História Brasileiras.

$\$ 3^{\circ}$. (VETADO)

Art. 79-A. (VETADO)

Art. 79-B. O calendário escolar incluirá o dia 20 de novembro como 'Dia Nacional da Consciência Negra'.

Art. $2^{\circ}$. Esta Lei entra em vigor na data de sua publicação. ${ }^{3}$ 
Desde sua sanção até o presente momento esta lei foi objeto de inúmeros debates que proporcionaram uma fortuna crítica bastante extensa, ainda mais porque no mesmo período ganham espaço no Brasil as políticas de ações afirmativas para a população negra. A Lei 10.639/2003, como se pode observar, altera o artigo 26 da LDB, colocando de maneira enfática a obrigatoriedade do ensino de História da África e das populações africanas e afro-brasileiras. $\mathrm{O}$ texto da lei permite a formulação de algumas inferências: a primeira, bastante evidente, é que essa temática vinha sendo negligenciada, ou seja, ela admite a negação/invisibilização desses conteúdos por parte da educação brasileira. Assim, a partir da promulgação da lei intensificou-se o debate em torno da obliteração dessa temática no meio educacional. Tal debate indicou, entre outras questões, a ausência de um número mais expressivo de profissionais especializados em história africana no Brasil, bem como localizou a falta de conteúdos referentes a esse tema na formação dos/das docentes. A situação no que diz respeito aos temas referentes à história e cultura afro-brasileira é um tanto diferente, pois nesse caso existia um número bem mais expressivo de profissionais aptos a lidar com o conteúdo. O problema consistia em esses assuntos se fazerem presentes na formação dos/das docentes (Costa, 2011).

Esse cenário de início dos anos 2000 vem dando sinais de reversão, muito em função da legislação aprovada e sancionada em 2003, fruto de uma luta de anos dos movimentos sociais da população negra. Os cursos superiores de História vêm buscando transformar as disciplinas sobre África, até então optativas raramente ofertadas, em disciplinas obrigatórias. Os concursos para docentes efetivos nessa área são evidências dessas mudanças. Por exemplo, em 2010 a Universidade Federal do Rio Grande do Sul (UFRGS) e a Universidade Federal do Rio de Janeiro (UFRJ) fizeram concursos para docentes nessa área. Em 2011 a Universidade Estadual de Campinas (Unicamp) abriu vaga, e no mesmo ano a Universidade Federal da Bahia (UFBA) realizou concurso para suprir a demanda. São estas algumas evidências da nova situação.

Mas, se por um lado esse reflexo da Lei 10.639/2003 pode ser entendido como positivo, por outro se torna relevante observar que entre as Universidades formarem profissionais e estes estarem em sala de aula existe um lapso de tempo considerável, os professores e professoras que já estão em sala podem não ter tido essa formação e, em teoria, têm a obrigação de trabalhar história e cultura africanas e afro-brasileiras. Nesse ponto pode surgir uma situação 
perigosa, mais perigosa, talvez, que a própria obliteração dessa temática, que é a abordagem por meio de visões estereotipadas, estigmatizantes, exotizantes, enfim, visões que venham a sacramentar posições oriundas do colonialismo, do racismo científico, da democracia racial.

As posições referentes à visão colonialista receberam críticas bastante apropriadas dos estudos pós-coloniais, bem como dos estudos culturais. As teorias feministas também colaboraram e colaboram na crítica à abordagem colonialista. ${ }^{4}$ Não são poucas as abordagens que explicitam o caráter racista da cultura ocidental, tais como o trabalho, já clássico, de Frantz Fanon. ${ }^{5}$ Sobre a história e a crítica ao racismo científico são muitas as obras disponíveis: podemos citar, entre outras, as de Tzvetan Todorov para a gênese do racialismo, sobre a ideia de raça o texto de Michael Banton e, para inserção dessas questões no cenário brasileiro, obras como as de Mariza Corrêa e de Lilia Moritz Schwarcz. ${ }^{6}$

Com efeito, a fortuna crítica da 'democracia racial', acerca da sua construção e desconstrução, é abundante. A ideia de que no Brasil não haveria preconceito de cor e raça não é nova, porém seu uso, mais sistematizado, pode ser localizado, especialmente, na década de 1880, ou seja, às vésperas da Abolição (1888). Por exemplo, Joaquim Nabuco (1849-1910) via a situação racial no Brasil assim:

A escravidão, por felicidade nossa, nunca azedou a alma do escravo contra o senhor - falando coletivamente - nem criou entre as duas raças ódio recíproco que existe naturalmente entre opressores e oprimidos. Por esse motivo, o contato entre elas foi sempre isento de asperezas, fora da escravidão, e o homem de cor achou todas as avenidas abertas diante de si. $^{7}$

A expressão 'democracia racial' não é, evidentemente, utilizada por Nabuco, porém é flagrante em seu discurso a construção de uma imagem de harmonia racial. Ele deixa nítido que uma vez encerrada a escravidão, todas as portas estariam abertas à população negra. Formalmente elas de fato estavam, mas apenas formalmente. Sílvio Romero (1851-1914) também não fez uso dessa expressão, todavia, seus escritos, em especial os da década de 1880, podem ser compreendidos como genitores da ideia do Brasil como 'democracia racial'. No primeiro tomo de sua História da Literatura Brasileira (1888) Romero positiva o mestiço como o elemento genuinamente brasileiro, fator de 
distinção da nacionalidade brasileira e de coesão do país. O mestiço romeriano é um mestiço de fenótipo branco, mas ainda assim um mestiço. ${ }^{8}$ Desse tipo de argumentação e já nesse período, fim do século XIX, surgia a ideia de que se o Brasil é mestiço, logo não haver no país espaço para o preconceito de cor nem para o preconceito racial.

Os antecedentes são vários, mas é atribuída a Gilberto Freyre (1900-1987) a formulação da ideia do Brasil como uma 'democracia racial'. Ele mesmo não utilizou a expressão em seus primeiros trabalhos de destaque, porém a ele foi dada a paternidade da ideia. Freyre abraçará a causa com vigor; talvez por isso a criação da ideia, bem como da expressão, seja vinculada a ele. Esse autor, em um estudo que pode ser entendido como comparativo das relações raciais entre brancos e negros nos Estados Unidos e no Brasil, afirmou não haver no segundo país as barreiras formais nem a perseguição explícita aos negros verificadas no primeiro. Também destacava a ausência de uma legislação segregacionista no Brasil como prova da inexistência de discriminação, já que o inverso acontecia nos Estados Unidos. Além disso, a larga miscigenação era tomada como a evidência máxima da ausência de preconceitos no Brasil. ${ }^{9}$ Entretanto, estudiosos posteriores começaram a se indagar acerca das conclusões propostas por Freyre. Mesmo durante a década de 1930, quando a revolucionária obra Casa-grande \& senzala foi publicada pela primeira vez, algumas vozes contestavam a sua visão das relações raciais no Brasil, em especial vozes vinculadas às organizações negras. Todavia, a crítica ao modelo freyriano só se sistematizará, por assim dizer, na década de 1950. Assim, o início da desconstrução da suposta democracia racial brasileira pode ser verificado, no que diz respeito à produção acadêmica, com os textos da equipe de Florestan Fernandes (1920-1995) e Roger Bastide (1898-1974), nas décadas de 1950 e $1960 .^{10}$

A Segunda Guerra Mundial (1939-1945) promoveu vários genocídios, muitos deles com algum tipo de motivação racial. Ao término do conflito tais práticas se tornaram objeto de reflexão. Estas, mais os dilemas e conflitos raciais espalhados por várias regiões do mundo, se tornaram um problema a ser investigado e, mais importante, solucionado. Assim, a recém-criada Organização das Nações Unidas (ONU) resolveu financiar um estudo sobre o Brasil, pois o país era considerado tanto externa quanto internamente (ao menos pela maioria) como o lugar da 'democracia racial', portanto livre de preconceitos raciais e dos conflitos decorrentes. ${ }^{11}$ Entretanto, as pesquisas empíricas 
patrocinadas pela ONU e desenvolvidas pela equipe de Florestan Fernandes e Roger Bastide revelaram outra realidade. As conclusões da equipe de Fernandes indicaram, ao invés da ausência de preconceito racial no Brasil, a sua presença em formas bem mais refinadas do que uma legislação segregacionista pura e simples. A discriminação racial no caso brasileiro se construía não pela sua afirmação, mas por sua negação. As atitudes e práticas discriminatórias se articulam em ações sutis, porém com efeitos nada sutis. Um deles é tão forte que promove a autoexclusão da população negra de inúmeros espaços, levando-a a entender de modo bem nítido o sentido da famosa frase: "no Brasil não tem essas coisas de racismo, porque preto sabe o seu lugar".

O processo de autoexclusão sugerido pela sociedade conduz parte significativa da população negra a nem tentar ocupar alguns espaços, uma vez que os relatos das 'barreiras' invisíveis são comentados no seio dessa população. ${ }^{12}$ E nesse ponto outro aspecto do 'racismo à brasileira' aparece com toda a força: o peso do racismo brasileiro só recai sobre os discriminados, pois os discriminadores não necessitam exercer o seu racismo, uma vez que este é construído como um não-problema. Logo, os discriminados reclamariam de algo que não existe.

Essa situação toda é bem expressa na assertiva de Fernandes (1971): “o preconceito de ter preconceito", de modo que o preconceito no Brasil não é demonstrado pela manifestação pública explícita - por exemplo, por meio de legislações segregacionistas. A discriminação e o preconceito racial se efetivam por meio de ações, em grande medida, implícitas. Obviamente elas são implícitas apenas para quem está na posição de discriminador, pois para quem está na condição de discriminado tais ações são bem explícitas (Costa, 2011).

Nesse contexto, por vezes a forma como se problematiza em sala de aula a história da África, de seus povos e civilizações, por mais que a intenção seja diversa, pode vir a reificar estereótipos e estigmas. A situação da história afro-brasileira não é diferente. Esta argumentação não quer de modo algum inferir que todo o conhecimento acerca da história e da cultura africanas e afro-brasileiras que se trabalhavam ou que se vêm trabalhando nas escolas detém estas características, mas sim que a formação em alguns casos inadequada de docentes pode levar à situação destacada anos atrás pela equipe de Florestan Fernandes e Roger Bastide. Ou seja, pode se configurar em mais uma forma sutil de discriminação, de estigmatização. Atentos a essa possibilidade, os Nú- 
cleos de Estudos Afro-brasileiros (NEABs) formados em várias universidades brasileiras também no contexto da Lei 10.639/2003 e das políticas de ação afirmativa vêm buscando levar a cabo cursos de formação de docentes na temática, no intuito de construir um novo olhar dos profissionais de educação sobre a África e suas populações, bem como acerca da população negra do Brasil, um olhar que escape às determinações racistas e discriminatórias. Em sendo a escola um espaço vital à conformação da visão de mundo das pessoas, a figura do professor torna-se igualmente fundamental. Assim, a formação de professoras e professores com uma visão de mundo mais aberta à diversidade cultural é essencial para a constituição de pessoas detentoras de condição semelhante. Em suma, a formação docente é passo mais do que fundamental para a construção de um novo olhar sobre a história e a cultura africanas e afro-brasileiras.

\section{BUSCANDO UM NOVO OLHAR}

A segunda seção desta argumentação, como mencionado anteriormente, aponta para uma sugestão de trabalho em sala de aula. Toma-se o contexto intelectual pós-abolição no Brasil, indicando como essa situação se articula ao senso comum e como este, por sua vez, se relaciona com a manutenção de estereótipos e estigmas acerca da população negra no Brasil, como indicado na seção anterior. A ideia subjacente a esta proposta é a tentativa de exemplificar a constituição dessa outra forma de olhar.

De maneira geral, até o ano de 1888 a sociedade brasileira tinha uma organização muito próxima àquela definida como estamental. Pois, mesmo existindo todo um setor de homens e mulheres livres vivendo e trabalhando durante a vigência do regime escravocrata, a sociedade dividia-se essencialmente entre pessoas livres e cativas, como bem indica Maria Sylvia de Carvalho Franco. ${ }^{13}$ Essa divisão básica pode ser entendida como marco essencial à composição do modo como ambos os grupos liam o mundo e com ele interagiam. E com isso não se descartam, evidentemente, as inúmeras divisões internas presentes tanto entre os livres (do senhor de escravos latifundiário até o trabalhador por jornadas) quanto entre a população cativa (do escravo com ofício ao trabalhador da lavoura), mas se destaca o marco básico à construção do modo de se lidar com o mundo. Desta feita, estamos a falar de uma socie- 
dade hierarquizada e organizada segundo uma diferença essencial entre as pessoas, a diferença entre livres e escravos. Após o decreto de 1888, que pôs fim à escravidão e formalizou que todos seriam iguais perante a lei, impôs-se uma alteração substancial no ordenamento básico da sociedade. ${ }^{14}$

A sociedade, até então pensada em termos de uma diferença clara e aberta, agora deveria se orientar pela igualdade. Contudo, é interessante lembrar que cerca de uma década antes da assinatura do decreto imperial já iam se constituindo, ao menos entre as elites intelectuais, novas maneiras de perceber o mundo. Nos anos 1870, como destacou João Cruz Costa (1904-1978), fazendo uso da expressão cunhada por Silvio Romero, chegou ao Brasil "um bando de ideias novas". ${ }^{15}$ Entre essas ideias está presente todo um jargão cientificista, positivista, como também as proposições referentes ao racismo científico. ${ }^{16}$ Tais proposições estavam em voga na Europa desde princípios do século XIX. Entretanto, o denominado racismo científico só adentrou o Brasil com alguma força quando a escravidão no país já apresentava nítidos sinais de esgotamento. As leis abolicionistas são sinal disso. Assim, uma das formas de pensar tal coincidência entre a proximidade da abolição, da equiparação jurídica das pessoas, e a entrada do racismo científico no Brasil pode estar na necessidade de demarcar posições na sociedade, ou seja, manter uma dada hierarquia (Costa, 2007a).

A indicação de Mariza Corrêa é extremamente pertinente, pois, para essa autora,

não parece ter sido apenas pela persuasão ideológica, apoiada em relações de favor entre as raças, que os negros e seus descendentes foram socialmente excluídos da participação de vários setores da vida pública brasileira, mas também pela manutenção de uma política autoritária em cuja definição a presença da discriminação não pode ser esquecida. Essa exclusão parece ter sido também o resultado de uma atuação coerente, apoiada por um racismo 'científico', que legitimou iniciativas políticas seja no nível nacional - como no caso dos privilégios concedidos à imigração que tiveram como consequência uma entrada maciça de brancos no país - seja em nível regional, como políticas específicas de repressão das atividades religiosas ou culturais dos negros ... Se não foi explicitado em leis civis discriminatórias, como a segregação racial norte-americana, o racismo, enquanto crença na superioridade de determinada raça e na inferioridade de outras, teve larga vigência entre os nossos intelectuais no período do final do século passado 
[século XIX] e início deste [século XX], sendo o ponto central de suas análises a respeito de nossa definição como povo e nação. (Corrêa, 2001, p.63)

Evidencia-se, assim, que não existe a necessidade de uma legislação específica para a efetivação de práticas discriminatórias. A divulgação e a assimilação de 'verdades científicas' que versam sobre a superioridade de uns e a inferioridade de outros acabam por ser incorporadas pelos atores sociais, e esses passam a atuar conforme esse papel. Por isso a relevância dos intelectuais empenhados em divulgar essas 'verdades científicas', pois no caso brasileiro eles são também deputados, senadores e ministros de Estado, ou seja, suas ideias são, em grande medida, transformadas em práticas de modo muito rápido. Basta lembrar que um proeminente divulgador - tardio, é bem verdade - do racismo científico, Francisco José de Oliveira Vianna (1883-1951), foi peça importante na elaboração teórica do Regime Vargas. ${ }^{17}$ As posições desses intelectuais atingiam muito rapidamente as gazetas e os manuais escolares. Aliás, é importante enfatizar a relevância da sala de aula para a divulgação desses ideais.

De pronto a pergunta a se estabelecer é como transportar este universo de discussão para a sala de aula, como discutir de modo menos áspero História das Ideias, História Intelectual, intelectuais, como demonstrar que essas figuras fazem, sim, parte do nosso dia a dia. ${ }^{18} \mathrm{O}$ meio mais recorrente, e nem por isso menos eficiente, consiste em citar trechos, num primeiro momento sem referenciá-los, e solicitar aos alunos seu debate, para posteriormente demonstrar quando e por que foram escritos, indicando a que demandas tais textos procuravam responder. Conforme a argumentação que se faz aqui, a utilização do racismo científico se dava com o intuito de manter determinada hierarquia social. Inúmeras premissas presentes nesses textos de fins do século XIX e do início do século XX tornaram-se parte indissolúvel do senso comum contemporâneo. Por exemplo, quase todo/a brasileiro/a detém consigo uma versão sua das palavras do intelectual sergipano Sílvio Romero. ${ }^{19}$ Escritas em 1888, dizem elas acerca da formação do povo local:

A história do Brasil, como se deve hoje ser compreendida, não é, conforme se julgava antigamente e era repetido pelos entusiastas lusos, a história exclusiva dos portugueses na América. Não também, como quis supor de passagem o romanticismo, a história dos tupis, ou, segundo o sonho de alguns representantes 
do africanismo entre nós, a dos negros no Novo Mundo. É antes de tudo a história da formação de um tipo novo pela ação de cinco fatores, formação sextiária em que predomina a mestiçagem. Todo o brasileiro é mestiço, quando não no sangue, nas ideias. Os operários deste fato inicial têm sido: o português, o negro, o índio, o meio físico e a imitação estrangeira. (Romero, 2001, p.57, grifo nosso)

Existe outra abordagem bastante interessante para demonstrar a presença dos intelectuais da virada do século XIX para o XX na nossa vida cotidiana: citar e problematizar algumas expressões, máximas e ditos populares vulgarmente utilizados mesmo na mídia. Vejamos:

- Não tinha cara de bandido!

- Olha só, com essa cara, só podia ser bandido mesmo!

- Carioca é tudo vagabundo!

- Baiano é tudo preguiçoso! Só sabem fazer festa!

- Hoje é dia de preto!

- Preto quando não faz na entrada faz na saída!

O que se sugere é o seguinte: com os alunos divididos em grupos, cada qual recebendo uma dessas frases ou outras do gênero, pedir a eles que discutam, segundo suas próprias opiniões, quais seriam as origens e as motivações por trás dessas assertivas. Com base nas considerações dos alunos, correlacionar as posições intelectuais que sustentaram e sustentam essas frases. Assim, as duas primeiras remetem à escola de criminalística italiana de Cesare Lombroso, ao movimento que levou à fundação do Instituto de Identificação na França, protótipo de todos os demais que hoje estão mundo afora. ${ }^{20} \mathrm{~A}$ escola de criminalística italiana propunha ser possível reconhecer um criminoso, ou, ainda melhor, um criminoso em potencial mediante sua composição física, notadamente do crânio, do formato deste, surgindo dessa argumentação uma especialidade que foi considerada ciência durante certo período: a craniometria. Atualmente essa perspectiva vigora com toda força nas duas primeiras assertivas listadas, bem como nas abordagens policiais e nos jornais sensacionalistas. Esse tema da previsibilidade do crime é tão recorrente que o cinema hollywoodiano, por exemplo, o visita constantemente. Logo, poder-se-ia trabalhar também com mais um mecanismo de problematização dessa questão: o filme Minority Report. Nele, a justiça e a ciência procuram deter o crimino- 
so antes do crime, embora sem recorrer à busca por 'caras de bandido'. Nesse sentido faz-se o monitoramento dos pensamentos, pois, por meio deles se localizaria o/a criminoso/a em potencial. ${ }^{21} \mathrm{Ou}$ seja, vigiando-se o pensamento, é possível monitorar o crime. Troca-se a aparência física pela aparência dos pensamentos para indicar o tipo criminoso. ${ }^{22}$

O nascimento dos institutos de identificação está intimamente ligado à perspectiva há pouco exposta. $\mathrm{O}$ instituto de identificação francês, pioneiro na área, tinha como grande objetivo localizar possíveis criminosos - identificar o tipo criminoso. Fazendo uso de métodos à época considerados científicos, como os da craniometria, o instituto procurou identificar e classificar a população parisiense na busca dos desviantes. Coincidentemente ou não, a construção 'científica' do protótipo do criminoso era exatamente igual à da população pobre da capital francesa, ou seja, o procedimento era em realidade mais um meio de estigmatizar, perseguir e oprimir a já sofrida população pobre de Paris. ${ }^{23}$ No Brasil tais teorias tiveram ampla aceitação; um dos seus mais proeminentes divulgadores foi o médico maranhense, radicado na Bahia, Raymundo Nina Rodrigues (1862-1906); todavia, esse intelectual nada mais fez do que dar 'cores de cientificidade' a algo já usual. ${ }^{24}$ Desde fins do século XIX, ou mesmo antes, a assertiva "cara de bandido" significa pobre, preferencialmente negro e/ou afrodescendente, e a sua oposta, "não tinha cara de bandido", refere-se a brancos, bem trajados, não pobres. Enfim, por trás de duas assertivas corriqueiras podemos discutir intelectuais e ciência do século XIX e princípio do século XX, a constituição de processos de discriminação e estigmatização que não dependem, necessariamente, de nenhuma legislação específica. ${ }^{25} \mathrm{Na}$ contemporaneidade a situação se alterou, contudo, a lógica das abordagens policiais não foge muito a esse princípio: tal questão pode ser trabalhada em sala de aula, por exemplo, com base na música Todo camburão tem um pouco de navio negreiro, do grupo O Rappa, donde se avalia a comunicação entre as premissas de fins de século XIX com as do início do século XXI no que diz respeito à estigmatização das populações negras e pobres. ${ }^{26}$

As assertivas que dizem "Carioca é tudo vagabundo!" e "Baiano é tudo preguiçoso!", ademais complementadas com outra máxima recorrente, "Só sabem fazer festa!", também é uma vertente importante desse processo de estigmatização oriundo do racismo científico do século XIX. Pois qual é o perfil da maioria da população, tanto da cidade do Rio de Janeiro quanto do próprio 
estado do Rio de Janeiro? E de Salvador, ou do estado da Bahia? A resposta é a mesma: a maioria da população é negra e afrodescendente. Com efeito, essas assertivas retomam aquilo que já era voga no período escravista: se não fosse a escravidão, negros e mulatos não trabalhariam: em razão de sua indolência nata, eles desatariam a ficar fazendo festas e batuques. Com o fim da escravidão o discurso muda um pouco e fica mais ou menos assim: negros e afrodescendentes não se mostram como sujeitos aptos ao trabalho livre, assalariado, em função da sua tendência natural à indolência e a ficar fazendo festas e batuques. Essa inaptidão de negros e afrodescendentes para o trabalho livre, assalariado, foi tema de intensos debates parlamentares no Brasil de fins do século XIX. A despeito da oposição de alguns parlamentares, o remédio apontado era o de trazer mão de obra da Europa, sobremaneira da Europa do Norte. Até mesmo o abolicionista Joaquim Nabuco entendia a imigração europeia como fundamental ao Brasil.

E quando se admite que negros e mulatos sejam de fato capazes de exercer funções no mercado de trabalho livre, a eles se reservam atividades braçais, de baixa remuneração e status, normalmente aquelas que são extremamente extenuantes, ou seja, atividades que mantêm viva a lembrança da escravidão - o animal de carga, o que executa tarefas de menor prestígio social, de subalternidade. $\mathrm{O}$ racismo científico configurou-se em propositor e divulgador, com outras vestes, de uma antiga vulgata - "O que é bom nasce feito!". Ou seja, da ideia das aptidões natas: alguns grupos são naturalmente aptos para isso ou aquilo, e não para outra coisa. Esse tipo de pensamento afirma que as populações negras não seriam biologicamente aptas a funções profissionais mais complexas, que exigissem maior capacidade intelectual. Logo, as ocupações profissionais histórica e socialmente construídas para os grupos negros e afrodescendentes brasileiros, por essa lógica, seriam aquelas passíveis de serem expressas na assertiva "Hoje é dia de preto!", que pode muito bem ser entendida como referência a um dia de trabalho pesado, difícil e mal remunerado. A manutenção de tais expressões no senso comum, especialmente do centro-sul do país, revela a intensa comunicação ainda existente entre a atualidade e a virada do século XIX para o XX no intuito de se manter certa visão de mundo. O trabalho escolar com história e cultura afro-brasileiras deve procurar desconstruir esse tipo de perspectiva, e nesse sentido deve-se entender sua construção e formas de manutenção. 
E aqui surge a necessidade de se abrir parênteses importantes, uma vez que atualmente discussões acerca das supostas aptidões natas das pessoas se revestem de outra vestimenta - a genética. Tal grupo de pessoas possui genes apropriados para isso e aquilo, e não para aquilo outro. Dado o alto desenvolvimento científico e tecnológico envolvido com as questões da genética, poucos se atrevem a problematizar algumas das afirmações originárias de suas proposições. ${ }^{27} \mathrm{Um}$ ponto de partida interessante para fomentar essa discussão em sala de aula vem de outra produção hollywoodiana: Gattaca. ${ }^{28}$ A trama se passa num futuro indeterminado, no qual a reprodução humana é toda assistida: escolhem-se os 'melhores' espermatozoides do pai e os 'melhores' óvulos da mãe para a realização de uma concepção in vitro, para posteriormente se introduzir o embrião no útero materno. Evidentemente, existem aqueles que discordam da prática e os que não podem pagar por ela: a esses resta o 'método antigo'. Não há nenhuma proibição a ele, contudo as pessoas que nascem dessa forma são consideradas geneticamente inferiores, pois não possuem os 'melhores' genes, logo só podem ocupar cargos subalternos. Isso não é de fato novo, é a nova roupa de uma doutrina antiga (Costa, 2007b).

O debate sobre profissões e ocupações é deveras interessante, pois ele pode servir tanto para destacar que no Brasil não há exclusão por critérios raciais quanto para o inverso, dependendo de 'quem fala' e 'de onde se fala'. As pessoas que compartilham da primeira posição indicam que o Brasil possui advogados/as, médicos/as, dentistas negros/as, mas não problematizam seu número em relação à população negra. Nos seus 123 anos de República, o Brasil já teve dois ou três governadores de estado negros, um ministro do Supremo Tribunal Federal, uns três ou quatro ministros de Estado igualmente negros, e atualmente algumas ministras. Essas situações são mobilizadas para corroborar a tese de que não há exclusão, muito pelo contrário. Entretanto, as pessoas que concordam com a segunda posição apontam: quantos médicos, dentistas e advogados negros conhecemos? Poucos. Se o sistema não fosse excludente, a proporção não deveria ser próxima à desse grupo na sociedade como um todo? Da seguinte forma: os dados indicam cerca de $40 \%$ da população brasileira composta por negros e afrodescendentes; dentre os médicos que conhecemos, por exemplo, $40 \%$ são negros/as? O caráter de excepcionalidade é marcante. E em muitos casos utiliza-se da exceção que confirma a regra para se bradar que o sistema não é excludente, aliás, é exatamente o 
contrário disso. Porém, é mais provável que, ao surgir uma exceção, a pessoa seja percebida na condição de intruso/a e, praticamente ao primeiro deslize, surja a assertiva que indica seu caráter de estrangeiro, de indesejado, de impertinente, num meio que não seria o seu: "Preto, quando não faz na entrada, faz na saída!”. Tal situação também pode ser apreendida como a materialização de outra expressão clássica da situação racial brasileira: "Não existe racismo no Brasil, pois aqui o preto sabe o seu lugar!". Não é esse um exemplo fantástico de internalização de papéis sociais? O da superioridade de uns e da inferioridade de outros, com manutenção do individualismo? Todos esses elementos remetem, então, para a permanência de um tipo de reflexão intelectual. Esta ocupa o lugar de uma legislação específica, pois sua ampla divulgação constrói barreiras invisíveis dentro dos indivíduos (Costa, 2007b).

A perpetuação dessas barreiras se dá por inúmeros instrumentos, alguns já apresentados aqui, mas um deles nos interessa sobremaneira: a atuação dos intelectuais de fins do século XIX e início do século XX. Raymundo Nina Rodrigues, Sílvio Romero e Euclides da Cunha, entre outros, estão vivos na representação que se faz de suas obras. A atuação desses e de outros intelectuais do período compreendido entre 1880 e 1930 é essencial para a construção e manutenção das barreiras invisíveis mencionadas. Suas considerações são peças-chave no processo de internalização e naturalização dos papéis sociais de superioridade e inferioridade presentes na sociedade brasileira. Nina Rodrigues indicava a respeito do povo brasileiro a necessidade premente de

determinar [o] quanto de inferioridade lhe advém da dificuldade de civilizar-se por parte da população negra que possui e se de todo fica essa inferioridade compensada pelo mestiçamento, processo natural por que os negros se estão integrando no povo brasileiro, para a grande massa de sua população de cor. ${ }^{29}$ [Pois] ... no Brasil, onde sobre eles [os negros], puros ou mestiçados, se levantou a nossa nacionalidade, cumpre julgá-los separadamente, discriminando as suas capacidades relativas de civilização e progresso. (p.13)

Essa discussão foi incorporada pela população negra em expressões que tratam da necessidade de 'clarear um pouquinho a raça', ou seja, a internalização da política do branqueamento mediante miscigenação, pela pessoa descendente de africanos. Romero, como já indicado, afirmava que todo brasileiro é mestiço - mas qual mestiço era esse? O intelectual sergipano idealizou um 
mestiço que não seria um qualquer, aleatório, mas um tipo específico e bem definido: seria o mais branco possível..$^{30} \mathrm{Em}$ suas próprias palavras: "o mestiço, que é a genuína formação histórica brasileira, ficará só diante do branco quase puro, com o qual se há de, mais cedo ou mais tarde, confundir" (Romero, 2001, p.101). Ele concorda aqui com outra posição interessante de Nina Rodrigues, o mestiço de retorno a uma suposta origem, neste caso "o mulato claro de retorno à raça branca" ${ }^{31} \mathrm{E}$ tudo isso acaba por se resumir em outra expressão bastante usual do dia a dia, "O brasileiro é isso, um pouquinho de tudo!”. Assertiva ambígua e complexa que, por um lado, refuta a pureza racial como um critério relevante e, por outro, impossibilita a discussão em torno dos mecanismos de discriminação no interior da sociedade brasileira. Tal assertiva foi desta forma inserida por Euclides da Cunha em Os sertões: "Não temos unidade de raça. Não a teremos, talvez, nunca". ${ }^{32}$ Para ele isso era motivo de lamentação. A falta de uma unidade racial era entendida como empecilho sério ao desenvolvimento do país. A ausência em questão seria a marca peremptória da suposta dificuldade do Brasil em desenvolver-se. Contemporaneamente, em conversas casuais, essa marca de origem, considerada ruim, é trazida à tona para sustentar argumentações acerca dos problemas brasileiros e da dificuldade em resolvê-los.

As assertivas citadas aqui são exemplos significativos da transposição de uma discussão intelectual para o cotidiano, sem que se perceba a complexidade do conteúdo presente. Estimular essa discussão é algo rico por alguns motivos.

1. Demonstrar o quanto os intelectuais estão presentes em nossa vida cotidiana, em vez de serem aquelas criaturas distantes, encurvadas, com óculos de lentes grossas e palavras esquisitas. Muito pelo contrário: eles estão no cotidiano, por meio da apropriação que fazemos de suas ideias, nos terminais de ônibus, nos botequins, nos estádios de futebol, na sala de jantar, no momento em que se assiste à telenovela.

2. Indicar como discussões intelectuais de fins do século XIX e do início do século XX, construídas para responder a determinadas demandas, se mantêm em forte comunicação com o contexto sócio-histórico contemporâneo e, em grande medida, ainda pelo mesmo motivo - justificar e ou manter uma dada hierarquia social. E, como indica Marisa Corrêa, 
essa apropriação, esse diálogo pode implicar a construção de um refinado sistema de discriminação que dispensou e dispensa a presença de um código legislativo formal. Ele se utiliza dos mecanismos de coerção estabelecidos. E pode contar com uma forma de coerção mais efetiva do qualquer equipamento externo poderia fornecer: aquela que o indivíduo exerce sobre si mesmo.

Com efeito, o presente artigo visou destacar a formação de docentes como extremamente relevante para a constituição de outro olhar sobre a História da África e de suas populações, bem como sobre a História afro-brasileira. Apontou as demandas resultantes da Lei 10.639/2003, a importância da promoção de atividade de capacitação para os/as docentes que não tiveram em suas graduações ou pós-graduações acesso à temática africana e afro-brasileira, para tentar desfazer visões estereotipadas. $\mathrm{O}$ artigo buscou, também, indicar a vinculação entre a discussão acadêmica e a vida cotidiana, bem como a comunicação entre fins do século XIX e o princípio do século XXI no que diz respeito à estruturação de certas hierarquias sociais, notadamente as raciais. Por fim, buscou exemplificar uma possibilidade de trabalhar conteúdos relacionados à história afro-brasileira sob outro olhar, almejando indicar a escola como local privilegiado para debater e criticar constructos intelectuais. Essa proposta se insere num processo mais amplo de transformação das/nas salas de aula brasileiras, que se espera venha desconstruir estereótipos arraigados e desenvolver uma visão de mundo antirracista.

\section{NOTAS}

${ }^{1}$ OLIVA, Anderson Ribeiro. A História da África nos bancos escolares: representações e imprecisões na literatura didática. Estudos Afro-Asiáticos, ano 25, n.3, p.431, 2003.

${ }^{2}$ COSTA, Hilton. Formação de professores: por um novo olhar da história e cultura afro-brasileira. In: PINHEL, André; COSTA, Hilton; SILVEIRA, Marco Silva da. (Org.) Uma década de políticas afirmativas: panorama, argumentos e resultados. Ponta Grossa (PR): Ed. UEPG, 2011.

${ }^{3}$ Disponível em: www.planalto.gov.br/ccivil_03/leis/2003/L10.639.htm.

${ }^{4}$ HALL, Stuart. Da diáspora: identidades e mediações culturais. Belo Horizonte: Ed. UFMG, 2003.

${ }^{5}$ FANON, Frantz. Pele negra, máscaras brancas. Salvador: Ed. UFBA, 2008. 
${ }^{6}$ TODOROV, Tzvetan. Nós e os Outros: a reflexão francesa sobre a diversidade humana. v.1. Rio de Janeiro: Jorge Zahar, 1993; BANTON, Michael. A ideia de raça. Lisboa: Ed. 70, 1979; CORRÊA, Mariza. As ilusões da liberdade: a escola Nina Rodrigues e a antropologia no Brasil. 2.ed. Bragança Paulista (SP): Ed. USF, 2001; SCHWARCZ, Lilia Moritz. O espetáculo das raças: cientistas, instituições e questão racial no Brasil, 1870-1930. São Paulo: Companhia das Letras, 1993.

${ }^{7}$ NABUCO, Joaquim. O abolicionismo. Brasília: Senado Federal, Conselho Editorial, 2003. p.40.

${ }^{8}$ ROMERO, Sílvio. História da Literatura Brasileira. Tomo I. Org. Luiz Antonio Barreto. Rio de Janeiro: Imago; Aracaju: UFS, 2001.

${ }^{9}$ FREYRE, Gilberto. Casa-grande \& senzala: formação da família brasileira sob o regime da economia patriarcal. 21.ed. Rio de Janeiro: J. Olympio, 1981.

${ }^{10}$ Sobre o projeto Unesco, ação que contemplava a equipe de F. Fernandes, ver MAIO, 1997; ver, também: COSTA, 2011.

${ }^{11}$ MAIO, Marcos Chor. A história do projeto Unesco: estudos raciais e ciências sociais no Brasil. Tese (Doutorado) - Instituto Universitário de Pesquisas. Rio de Janeiro, 1997.

${ }^{12}$ Entre outros, podemos citar: FERNANDES, Florestan. O negro no mundo dos brancos. São Paulo: Difusão Europeia do Livro, 1971; PEREIRA, João Baptista Borges. Cor, profissão e mobilidade: o negro e o rádio de São Paulo. São Paulo: Pioneira; Ed. USP, 1967; TELLES, Edward. Racismo à brasileira: uma nova perspectiva sociológica. Rio de Janeiro: Relume Dumará, 2003; GUIMARÃES, Antônio Sérgio Alfredo. Racismo e anti-racismo no Brasil. São Paulo: Fundação de Apoio à Universidade de São Paulo; Ed. 34, 1999;

Classes, raças e democracia. São Paulo: Fundação de Apoio à Universidade de São Paulo; Ed. 34, 2002; Preconceito e discriminação. São Paulo: Fundação de Apoio à Universidade de São Paulo; Ed. 34, 2004.

${ }^{13}$ FRANCO, Maria Sylvia de Carvalho. Homens livres na ordem escravocrata. 4.ed. São Paulo: Ed. Unesp, 1997.

${ }^{14}$ COSTA, Hilton. Hierarquias brasileiras: a abolição da escravatura e as teorias do racismo científico. Comunicação apresentada no III Encontro ESCRAVIDÃO E LIBERDADE NO BRASIL MERIDIONAL. Florianópolis, 2007a.

${ }^{15}$ COSTA, João Cruz. Contribuição à História das ideias no Brasil. 2.ed. Rio de Janeiro: Civilização Brasileira, 1967.

${ }^{16}$ Cientificismo é uma crença desenvolvida em fins do século XVIII e amplamente divulgada no transcorrer do século XIX, que defende a ideia de humanidade genérica desenvolvendo-se de modo linear do menos ao mais avançado, definição clássica de progresso, e tal desenvolvimento só seria possível, bem como sua compreensão e aprimoramento, através da ciência; Positivismo pode ser lido como uma sistematização das crenças cientificistas, realizada por Auguste Comte: ele apregoa que toda explicação e todo conhecimento advêm da ciência e pela ciência; Racismo Científico, doutrina que defendia a existência de raças 
humanas distintas entre si; apesar de poderem se combinar, o resultado dessa ação geralmente era considerado ruim, e tais diferenças eram cientificamente passíveis de comprovação, definindo de modo definitivo a superioridade de uns e a inferioridade de outros.

${ }^{17}$ Francisco José de Oliveira Vianna nasceu em Saquarema, estado do Rio de Janeiro, em 1883, e faleceu na cidade do Rio de Janeiro em 1951. Bacharel em Direito, historiador e sociólogo, foi consultor jurídico do Ministério do Trabalho e ministro do Tribunal de Contas; também foi membro da Academia Brasileira de Letras e do Instituto Histórico e Geográfico Brasileiro. Entre suas principais obras figuram: Populações meridionais do Brasil (1920), O idealismo na evolução política do Império e da República (1922), A evolução do povo brasileiro (1923), Problemas de política objetiva (1930), Raça e assimilação (1932), Formação étnica do Brasil colonial (1932) e Instituições políticas brasileiras (2v., 1949), todas elas marcadas por forte conservadorismo. Os conservadores sempre constituíram um grupo determinante na História das Ideias, e essas obras são consideradas como um momento importante dos estudos brasileiros.

${ }^{18}$ Definições bastante acessíveis acerca do que pode ser compreendido por História das Ideias e História Intelectual são encontradas em CARDOSO, Ciro Flamarion; VAINFAS, Ronaldo (Org.) Domínios da História: ensaios de teoria e metodologia. Rio de Janeiro: Campus, 1997.

${ }^{19}$ Sílvio Vasconcelos da Silveira Ramos Romero nasceu em Lagarto, Sergipe, em 21 de abril de 1851, e faleceu em 18 de julho de 1914, no Rio de Janeiro. Bacharel em Direito, foi professor do Colégio Dom Pedro II e da Faculdade de Ciências Jurídicas e Sociais do Rio de Janeiro, membro da Academia Brasileira de Letras, do Instituto Histórico e Geográfico Brasileiro e sócio correspondente da Academia de Ciências de Lisboa.

${ }^{20}$ Cesare Lombroso nasceu em Verona no dia 6 de novembro de 1835 e faleceu em Turim em 19 de outubro de 1909. Formou-se em medicina na Universidade de Pavia em 1858, e no ano seguinte na Universidade de Gênova. Depois de formado, segue para Viena para aperfeiçoar seus conhecimentos e lá se alinha ao pensamento positivista. Desde cedo demonstra interesse em estudos sobre a loucura, mas logo se volta para uma vertente mais antropológica. Essas observações têm início em Pavia, num curso de psiquiatria. Daí lança hipóteses acerca da influência do meio sobre a mente. Dirige o manicômio de Pádua de 1871 a 1876, ano em que assume a cadeira de Higiene e Medicina Legal da Universidade de Turim. Nesse mesmo ano publica sua primeira obra sobre criminologia, onde já aparece a influência da 'frenologia': O homem delinquente.

${ }^{21}$ MINORITY REPORT. Dir. Steven Spielberg, com Tom Cruise, Estados Unidos, 2002.

${ }^{22}$ COSTA, Hilton. A vida do senso comum: do racismo científico do pós-abolição ao dia a dia contemporâneo. In: COSTA, Hilton; SILVA, Paulo Vinicius Baptista da. Notas de história e cultura afro-brasileiras. Ponta Grossa (PR): Ed. UEPG, 2007b.

${ }^{23}$ Sobre o instituto de identificação parisiense há reflexão breve, mas interessante em SCHWARCZ, 1993.

${ }^{24}$ Raymundo Nina Rodrigues nasceu em 4 de dezembro de 1862 na cidade de Vargem 
Grande, Maranhão, e faleceu em 17 de julho de 1906 em Paris. Médico e antropólogo, foi o fundador da medicina legal no Brasil e um dos precursores da antropologia.

${ }^{25}$ GOFFMAN, Erwing. Estigma: notas sobre a manipulação da identidade deteriorada. 4. ed. Rio de Janeiro: LTC, 1988.

${ }^{26}$ Todo camburão tem um pouco de navio negreiro. Letra: Marcelo Yuka; Música: O Rappa; Álbum O Rappa, 1994.

${ }^{27}$ LE BRETON, David. O corpo rascunho das ciências da vida. In: Adeus ao corpo: antropologia e sociedade. Campinas (SP): Papirus, 2003. p.101-140.

${ }^{28}$ GATTACA. Dir. Andrew Niccol, com Ethan Hawke e Uma Thurman, Estados Unidos, 1997.

${ }^{29}$ RODRIGUES, Raymundo Nina. Os africanos no Brasil. 7.ed. São Paulo: Cia. Ed. Nacional; Brasília: Ed. UnB, 1988. p.264.

${ }^{30}$ COSTA, Hilton. Horizontes raciais: a ideia de raça no pensamento social brasileiro. 1880-1930. Dissertação (Mestrado) - Programa de Pós-Graduação em História, UFRGS. Porto Alegre, 2004. p.94.

${ }^{31}$ ROMERO, Sílvio. As raças humanas e a responsabilidade penal no Brasil. 3.ed. São Paulo: Cia. Ed. Nacional, 1938. p.119-121.

${ }^{32}$ CUNHA, Euclides da. Os sertões. 39.ed. Rio de Janeiro: Livr. Francisco Alves, 1997. p.94.

Artigo recebido em 20 de dezembro de 2011. Aprovado em 11 de abril de 2012. 